\title{
Campus Culture Construction in Transition of Application-oriented Undergraduate Education
}

\author{
Jian-Guo LUO ${ }^{\mathrm{a}}$, Min ZHANG ${ }^{\mathrm{b}}$ \\ School of mechanical and electrical engineering, North China Institute of Science and \\ Technology, Beijing, China \\ aluojg_1598@126.com, b'zhangmin_0124@163.com \\ ${ }^{*}$ Corresponding author
}

Keywords: Campus culture construction, Application-oriented undergraduate education, Professional characteristics.

\begin{abstract}
Campus culture construction is an important content in transition of application-oriented undergraduate education. In this paper, the connotation of campus culture construction is defined and the significance is discussed. Lacking of attention and professional characteristics are widespread problems. Aiming at these concerns, some strategies are presented to improve campus culture construction of application-oriented colleges.
\end{abstract}

\section{Introduction}

Campus culture is the essence and soul of the college, which is closely related to the its running characteristics. Campus culture of application-oriented undergraduate education refers to the human atmosphere and spirituality of all the teachers and students under specific talent training objective and training mode. Compare to traditional colleges, career-oriented campus culture is a remarkable feature of application-oriented colleges, embedded in more professional skills and more occupational ethics[1]. It is established in the long teaching procedure, and is the sum total of values, morals, behavior standards and lifestyles of the teachers and students.

Different to common colleges, application-oriented colleges should pay more attention to the connotation construction of campus culture, introduce industry culture, and enterprise culture into classroom teaching, organic combination of humanistic care, professional feelings and enterprising spirits, to built the campus culture from the aspect of material culture, spiritual culture and system culture in all-round way.

\section{Significance of campus culture construction in transition of application-oriented undergraduate education}

\section{Talents training function of campus culture construction}

The talents cultivation function of campus culture is embodied in moral education, intellectual education, sports and aesthetic education.

The moral education function of campus culture mainly reflected in the guidance of values and behavior orientation to each member and the whole campus. The world outlook, outlook on life, values of the college students have not yet formed, their minds are not mature enough to face the complex domestic and international situation, especially various temptations from 
network virtual world[2]. Correctly moral guiding can cause college students not to get lost in all kinds of conflicts and confusions.

Classroom teaching is the main battlefield and of various campus cultural activities, and also is an important withdrawal of intellectual education function. Furthermore, the colorful extracurricular cultural life (such as various academic lectures, club activities) can form an "invisible classroom", provide students with different interests and hobbies, and expand their knowledge.

The sports function of campus culture, also known as the physical and mental cultivation function, mainly refers to its effects on physical and mental health of the teachers and students. In the narrow sense, it refers to the function of psychological adjustment, on the other hand, it refers to entertainment function in a broad sense.

Campus culture has potential educational effect on the aesthetic education factors, resulting in deep infiltration and influence on the outer beauty and inner beauty of the students[3]. It can cultivate and enhance students' ability to experience beauty, identify beauty, appreciate beauty and create beauty, as well as help students to set up the correct aesthetic and scientific aesthetic ideal.

\section{Innovation function of campus culture construction}

Innovation function of campus culture refers to the innovation factors of it contains, and motivation on the innovation consciousness, innovation potential, innovation methods of talents. Campus culture construction constantly absorbs new ideas, new theories and new science, create and update culture for society, promote social culture development, and create a good creative atmosphere for the innovative talents cultivation[4,5].

\section{Socialization function of campus culture construction}

In the new period, the socialization function of campus culture mainly refers to the spirit, habits, and morality required by social reality. By building spiritual environment and cultural atmosphere, it can create imperceptible influence to the life in the college campus, especially college students, make them form consistent with the social requirements on thought idea, the behavior way, value orientation, etc.

The socialization function of campus culture embody in the following areas: i) Promote the socialization of political life of college students. ii) Promote the socialization of life goals of college students. iii) Promote the socialization of value orientation of college students. iv) Promote the socialization of college students' ethics. v) Promote the socialization of student role playing. vi) Promote the socialization of college students' personality.

\section{Status analysis of campus culture construction in transition of application-oriented undergraduate education}

At present, the campus culture construction of application-oriented undergraduate education level is still in the primary stage, and cannot be closely connected with its own characteristics, the main problems are analyzed here.

\section{Backward campus culture concept and weak enterprise culture foundation}

Most of the application-oriented colleges lack scientific and systematic planning, and also have no professional guiding teachers on culture activities[6]. Students have not much 
involvement in it resulting in unsatisfactory effects. The enterprise construction of campus culture is neglected and not updated in time, so the campus culture is dominated by the traditional content, which is not suitable for the special target of education talents training. Due to the hysteresis of campus culture in application-oriented colleges, the campus culture is lack of industry characteristics and is out of touch with the enterprise culture.

\section{More attention on skill training, despise the humanity education}

Carrying out campus cultural activities should not only help students deepen their knowledge and skills, but also promote comprehensive quality improvement. However, many application-oriented colleges still attach importance to the cultivation of skills, and pay more attention to the work with quick results[7]. There is a serious lack of attention and input to the hidden and potential campus cultural construction. Fig.1 shows the investigation results of campus culture construction happened in North of China of Science and Technology. The number of participants are 40, including 20 teachers and 20 students. It shows that most of the participants think that campus culture construction is very necessary, but there are still some participants lack of recognition and attention on it. Furthermore, more focused on campus culture of students are shown than that of teachers.

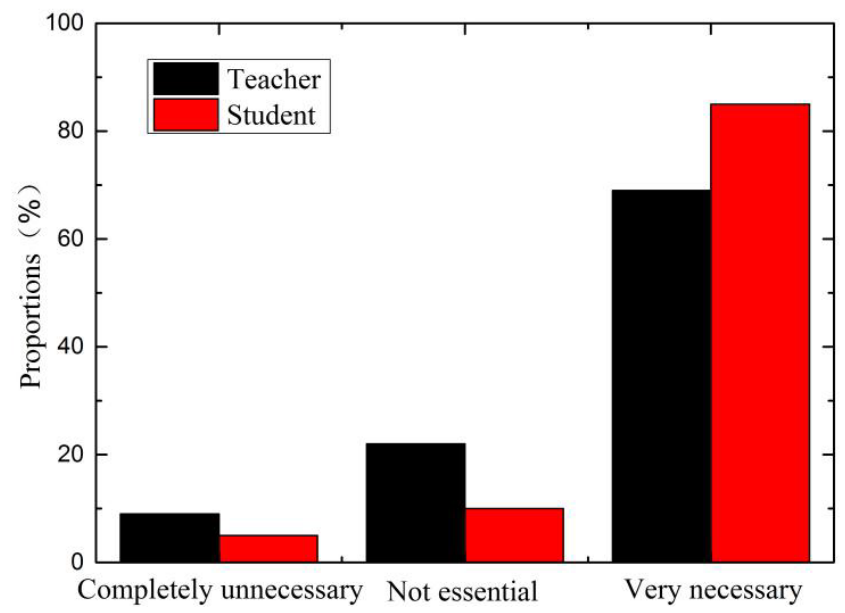

Fig. 1 The necessity investigation of campus culture construction

\section{Ambiguous school running concept, miss characteristic cultures}

Not bright characteristic is also a prominent problem of campus culture construction of application-oriented colleges. The school running concept is not clear enough, most colleges and universities only consider campus culture construction from the aspects of professional setting, teaching staff, management system and so on, but the "professional"characteristic is insufficient.

\section{Strategies design of campus culture construction in transition of application-oriented undergraduate education under new situation}

\section{Establish new working system of campus culture construction}

Fig.2 shows the new working system of campus culture construction. A college-level leading department of campus culture construction is established, it is responsible for organizing and managing the campus cultural activities of the sub-departments, and also it is supervised by the 
party and government department and the academic affairs department of the college. In this way, the college can carry out campus cultural activities comprehensively and systematically, and ensure the smooth development of campus culture construction.

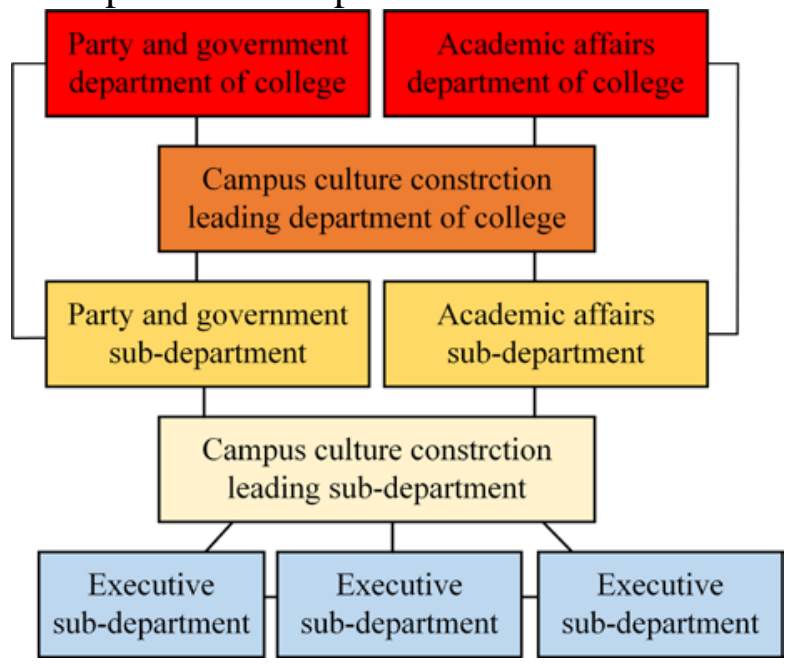

Fig. 2 Working system of campus culture construction

\section{Building platforms of campus culture construction}

The campus culture platforms mainly include teacher platform, major platform and practical training platform.

Teachers are the conductors of culture, having a "double teacher" structure teaching team is the key to improve the quality of campus culture. By increasing the cooperative exercise between teachers and enterprises can effectively enhance the professional quality of teachers.

The construction of characteristic campus culture of higher vocational colleges can not be separated from the characteristic major, and the success or failure is reflected in the professional setting. Therefore, we should strengthen the construction of professional culture, make efforts to realize the transformation from "theoretical" to "technical", as well as from "disciplinary" to "modular".

The practical training is an important link to realize the integration of campus culture, industry culture and enterprise culture, which can enhance students' adaptability to the professional post group. Relying on industry, colleges should actively seek cooperation opportunities with enterprises to form a good training platform for the students.

\section{Optimizing environment of campus culture construction}

Optimizing environment of campus culture construction manifests as teaching environment entrepreneurial and teaching content professional.

Colleges should strive for the support of enterprises with large scale, strong technology and advanced management to strengthen off-campus practice, or build off-campus practical training base together with these enterprises, leading to an effective platform and featured education environment.

Colleges also should cultivate the students' team spirit and professional quality, professional ethics, let students feel the corporate culture by themselves. So that student's comprehensive quality will be improved, school characteristics will be strengthened and the whole teaching quality will gradually increase. 


\section{Summary}

In this paper, connotation and significance of campus culture construction of applicationapplied undergraduate colleges are shown and discussed. The status of campus culture construction are investigated and many problems are found. Some strategies are advised to private the campus culture construction.

\section{Acknowledgement}

This research was financially supported by the Advanced Education Research Foundation of Hebei Province.

\section{References}

[1] Liu Shuai. Research on the construction of university campus culture in the vision of ideological and political education[D]. Central China Normal University, 2015.

[2] Liu Longhai. Strengthening the construction of university campus culture and realizing the management of people oriented [J]. China Higher Education Research, 2007(1):84-85.

[3] Mo Zhen Min. Independent Colleges in the New Problems and Countermeasures of Campus Culture Construction [J]. Modern Enterprise Education, 2012 (17): 68.

[4] Lei Yali. The Study of the Innovation Quality Training of College Students Based on Campus Culture Construction[D]. Hubei University of Technology, 2017.

[5] Jun Youfeng. Cultural construction and improve students moral and intelligence research[D]. Fujian Normal University, 2013.

[6] Liu Huifang, Ye Yunfeng, Cheng Min. Study on Reasons of Campus Culture loss in Private Colleges and Constructing Approaches [J]. The Guide of Science and Education, 2015(12):17-18.

[7] Gao Ming, Xing Jiangfei. Difficulty and countermeasures of harmonious campus culture construction [J]. Chinese Higher Education, 2010(13):95. 